\title{
The effect of liquid tumeric extract supplementation on carcass production and chemical quality of broiler meat
}

\author{
M. Hidayat ${ }^{1}$, Zuprizal $^{1}$, Sundari ${ }^{2}$, A. Kurniawati ${ }^{1}$, A. K. Wati ${ }^{3}$ and A. Kusmayadi ${ }^{4}$ \\ ${ }^{1}$ Faculty of Animal Science, Universitas Gadjah Mada, \\ Jl. Fauna No. 3 Bulaksumur, Yogyakarta 55281 \\ ${ }^{2}$ Department of Animal Science, Faculty of Agroindustry, Universitas Mercu Buana, \\ Jl. Wates Km 10 Yogyakarta-Indonesia \\ ${ }^{3}$ Department of Animal Science, Faculty of Agriculture, Universitas Sebelas Maret, \\ Jl. Ir. Sutami 36 A Kentingan Surakarta 57126 - Indonesia \\ ${ }^{4}$ Department of Animal Science, Faculty of Agriculture, Universitas Perjuangan, \\ Jl. Peta No. 177, Tawang, Tasikmalaya - Indonesia \\ Corresponding E-mail : muhammad.hidayat93@mail.ugm.ac.id
}

Received August 23, 2016; Accepted January 03, 2017

\begin{abstract}
ABSTRAK
Tujuan penelitian ini adalah untuk mengetahui efek penambahan ekstrak kunyit sediaan cair (EKC) sebagai fitobiotik terhadap produksi karkas dan kualitas kimia daging ayam broiler. Penelitian dilakukan dengan rancangan percobaan acak lengkap pola searah. Ayam broiler 84 ekor dipelihara sejak usia 0 hingga 42 hari. Umur 0-14 hari diberi pakan komersial (ME: $3100 \mathrm{kcal} / \mathrm{kg}$; CP 22\%; Ca 1\%; P 0,75\%). Umur 15-21 hari diberi pakan campuran komersial dan basal (ME 3201,77 kcal/kg; CP 20,21\%; Ca 0,90\%; P 0,43\%). Umur 22-42 hari dimulai perlakuan dengan diberi pakan basal. Tujuh perlakuan dibuat dengan masing-masing 3 replikasi dan 4 ekor di setiap replikasi, dengan formulasi pemberian EKC sebagai berikut; kontrol positif (P1), kontrol negatif (P2), air + EKC 2\% (P3), air + EKC 4\% (P4), air + EKC 6\% (P5), air + EKC 8\% (P6), dan air + EKC 10\% (P7). Hasil penelitian menunjukkan pemberian EKC konsentrasi $10 \%$ menurunkan secara nyata $(\mathrm{P}<0,05)$ bobot potong dan konsentrasi $8 \%$ dan $10 \%$ menurunkan secara nyata $(\mathrm{P}<0,05)$ kadar air daging, tetapi tidak menunjukkan pengaruh nyata $(\mathrm{P}>0,05)$ terhadap bobot karkas, persentase karkas, protein dan lemak daging.

Kata Kunci: ayam broiler, fitobiotik, ekstrak kunyit cair, produksi karkas, daging
\end{abstract}

\begin{abstract}
The purpose of this research was to find out the effects of liquid turmeric extract (LTE) supplementation as a phytobiotic on carcass production and chemical quality of broiler chicken meat. The research is conducted with a directional pattern completely randomized design. Eighty-four broiler chickens were raised from day old (DOC) to 42 days old chick. From DOC to 14 days old chicks were fed with commercial feed (ME 3,100 kcal/kg; CP 22\%; Ca 1\%; P 0.75\%). During 15-21 days of age given a commercial feed mixture and basal feed (ME 3,201.77 kcal/kg; CP 20.21\%; Ca 0.90\%; and P $0.43 \%$ ). At 22-42 days old given treatments. Seven treatments were replicated 3 times consisted of 4 broiler chickens for each replication. The treatments were positive control (P1), negative control (P2), water + LTE 2\% (P3), water + LTE 4\% (P4), water + LTE 6\% (P5), water + LTE 8\% (P6), and water + LTE $10 \%$ (P7). The results showed that LTE $10 \%$ significantly decreased $(\mathrm{P}<0.05)$ on the slaughter
\end{abstract}


weight and $8 \%$ until $10 \%$ dossage had a significant decrease $(\mathrm{P}<0.05)$ on the meat water content. However, it did not show a significant influence $(\mathrm{P}>0.05)$ on the carcass weight, carcass percentage, meat protein and fat content.

\section{Keywords: broiler chicken, phytobiotic, liquid turmeric extract, carcass production, meat}

\section{INTRODUCTION}

The contribution of Indonesia's animal farm in providing sufficient feed as a source of animal protein, especially meat, greatly depends on poultry meat, more specifically broiler meat. Data from the Badan Pusat Statistik (2015) reveal that the average production of broiler meat in Indonesia from 2012 until 2014 was 52.03\% of total national meat production with a broiler meat consumption of $86 \mathrm{~g} / \mathrm{capita} / \mathrm{week}$, so that Indonesian society will lose more than half of animal protein feed from domesticated meat whenever there is no production of broiler meat.

Broilers in Indonesia usually are reared using antibiotics as a feed additive produced by local feed companies in Indonesia. The antibiotics added in feed are usually used as a treatment and prevention of infections (Barton, 2000) and growth promoter (Barton, 2000; Dono, 2012; Daud et al., 2007; Hartadi et al., 2008) to improve the growth of broilers. Dono (2012) clarified that the effect of growth promoting antibiotics is strongly correlated with its ability to inhibit pathogenic microbes in the digestive tract. As a consequence, by inhibiting the growth of pathogens and reducing the toxic compounds from bacteria metabolism, it can stimulate the digestive efficiency and support the acceleration of the growth. In addition, according to Ajit et al. (2016), the beneficial effects of using antibiotics include the thickening of the intestine which leads to more nutrient absorption. Antibiotics that are frequently used as growth promoters include zinc bacitracin (Daud et al., 2007; Bintang et al., 2008), oxytetracycline (Hintono et al., 2007), virginiamycin (Sinurat et al., 2009), flavomycin (Ashayerizadeh et al., 2009; Gunal et al., 2006), and enrofloksasin (Widiastuti, 2008).

However, using antibiotics as a growth promoter in feed has various deficiencies. Widiastuti (2008) explained that the use of antibiotics as a growth promoter produces antibiotic residue in broiler liver, breast, and thigh meat. Antibiotic residue tends to be dangerous when considering that the antibiotics used in poultry are the same as those used by humans.

Several kinds of medicinal plants can be used as antibiotic replacements in poultry. This is caused by the presence of active compounds in the plants that have a positive effect on the human body's health. Turmeric is one of the plant containing curcumin that functions as antibacteria (Rahmawati et al., 2015; Fitoni et al., 2013). Bhawana et al. (2011) stated that the curcumin anti-bacteria working mechanism is examined with a transmission electron micrograph (TEM) analysis, which reveals that these particles enter bacteria cell walls by completely damaging the cell walls, resulting in cell death. The presence of this curcumin antibacteria characteristic is expected to have the same function as an antibiotic characteristic in inhibiting pathogenic bacteria in the small intestine, which will then result in better broiler growth. Curcumin, according to Prasanth et al. (2012), also has an antihiperlipidemic function. They elaborated further that curcumin has a derivative compound from the hydrogenation process that is called tetrahydrocurcumin (THC), which is an antioxidative substance that possesses an anti-hyperlipidemic effect by reducing peroxide lipids and lipid compounds (cholesterol, triglyceride, free fatty acid, and phospholipid). This function will be beneficial when considering that broiler have a high fat content, so that the presence of additional curcumin is expected to be able to improve the carcass quality by reducing the broiler meat fat content.

The curcumin active compound still has a deficiency related to its minimal systemic bioavailability (absorption) in digestion (Sundari, 2014). Other compounds need to be added in turmeric extract to optimize the function of curcumin. Research by Sundari (2014) shows that adding the compounds chitosan and sodium tripoliphosfate (STPP) are known to be able to cover the weaknesses of curcumin in the digestion process. Chitosan functions to improve the solubility and bioavailability of curcumin, while STPP acts to stabilize turmeric extract and chitosan by performing as a cross-linker. Sundari (2014) also reported that the formulation of turmeric extract + chitosan + STPP with turmeric extract dissolvent and ethanol dissolvent produces high production cost of $\mathrm{Rp} 6,060.00 / \mathrm{g}$, so that 
water could replace ethanol to reduce the production cost.

The purpose of this research is to discover the influence of adding liquid turmeric extract as a phytobiotic towards carcass production and broiler meat chemical quality as well as to find out the best concentration of liquid turmeric extract to produce carcass production and broiler meat chemical quality.

\section{MATERIALS AND METHODS}

\section{Instruments}

The instruments used in this research consisted of a group of 21 square cages measuring p x $1 \times \mathrm{t}=80 \times 50 \times 50 \mathrm{~cm}$, a chicken scale, food containers, drink containers, a thermometer and room hygrometer, a chicken and feed scale, a 500 $\mathrm{ml}$ measuring glass, a $50 \mathrm{ml}$ measuring glass, a set of chicken slaughtering equipment, and a set of meat proximate chemical analysis equipment.

\section{Materials}

The materials used in this research were one day old chicks (DOC) of male broilers, commercial feed, starter and finisher broiler formulation basal feed, drinking water, vitamins, ND 1 and ND 2 vaccines, fumigation material, fresh turmeric, chitosan, citric acid, and sodium tripolyphosphate (STPP).

\section{Process of Making Liquid Turmeric Extract}

The steps of making liquid turmeric extract were as follows: 1) fresh turmeric was peeled; 2) the peeled turmeric was bleached with citric acid solution of $0.05 \%$ until it was all submerged in a temperature of $100^{\circ} \mathrm{C}$ for 5-10 minutes, and then it was thinly sliced; 3) the sliced turmeric was then mixed with distilled water and blended (a mixture of $400 \mathrm{~g}$ of fresh turmeric dissolved in $500 \mathrm{ml}$ of distilled water); 4) the blended turmeric was then filtered, the dregs separated, and put through a filtrate; 5) the turmeric extract filtrate was then added with $5 \mathrm{~g}$ of chitosan that had previously been dissolved in a $400 \mathrm{ml}$ buffer of $\mathrm{pH} 4$ citric acid using magnetic stirrer; 6) the extract filtrate of turmeric + chitosan was added with $2.5 \mathrm{~g}$ of STPP, which previously had already been dissolved in $100 \mathrm{ml}$ of distilled water using magnetic stirrer.

\section{In vivo Test of Liquid Turmeric Extract}

Male broilers were raised for 42 days. From day old chick (DOC) to 14 days of age, the broilers were given commercial feed with $\mathrm{ME}$ nutrient content of: 3,100 Kcal/kg; CP 22\%; Ca $1 \%$; P $0.75 \%$. From 15 to 21 days of age, the broilers were given commercial feed and starter basal feed (Table 1) to adapt with the consumption of basal feed that was free of antibiotics, so that it could all be used in basal feed when given turmeric extract.

Eighty-four broilers of 22 days old were divided randomly into 7 treatment groups. Each treatment consisted of 3 replications with 4 broiler in every replication. The treatments were applied for 21 days until the chickens reached 42 days old. The broiler grower basal feed (Table 1) was given ad libitum during the treatments. Seven treatments were differentiated based on the addition of turmeric extract in the drinking water, including:

T1 : positive control (water + antibitotic Zinc Bacitracin $12 \mathrm{mg} / 1000 \mathrm{ml}$ )

$\mathrm{T} 2$ : negative control (water)

$\mathrm{T} 3$ : water $+2 \%$ liquid turmeric extract

$\mathrm{T} 4$ : water $+4 \%$ liquid turmeric extract

T5 : water $+6 \%$ liquid turmeric extract

T6 : water $+8 \%$ liquid turmeric extract

T7 : water $+10 \%$ liquid turmeric extract

\section{Parameters Observed}

Parameter observed included carcass production (slaughter weight, carcass weight, and carcass percentage) and meat chemical quality (water content, meat protein content, and meat fat content). The slaughter weight was obtained by weighing the chickens before being slaughtered. Two broilers were slaughtered in every replication of each treatment. The carcass weight was obtained by slaughtering the chickens until all the blood was removed and then separated from the feathers, head, internal organs, and feet, then it was weighed. The carcass percentage was obtained by dividing the carcass weight by the slaughter weight and multiplied by $100 \%$. Meat from the right thigh was sampled and blended for chemical analysis included water content, crude protein content, and crude fat content using AOAC (2005). Data were analyzed with a directional pattern method using SPSS-16 program, and if there was a significant difference $(\mathrm{P}<0.05)$, then an Orthogonal Contrast Test (Astuti, 1980) was used for further analysis. 
Table 1. Composition and Nutritional Content of Basal Feed*

\begin{tabular}{lrr}
\hline \multicolumn{1}{c}{ Feed Stuffs } & \multicolumn{1}{c}{$\begin{array}{c}\text { Starter } \\
(\%)\end{array}$} & \multicolumn{1}{c}{$\begin{array}{c}\text { Finisher } \\
(\%)\end{array}$} \\
\hline Milled yellow corn & 52.00 & 52.00 \\
Rice bran & 10.00 & 12.50 \\
Soybean meal / SBM 45 & 21.00 & 0.50 \\
Fish flour 55 & 12.00 & 9.50 \\
Palm oil & 3.70 & 5.10 \\
Limestone & 0.13 & 0.30 \\
Salt NaCl & 0.08 & 0.20 \\
Masamix ** & 0.44 & 0.10 \\
L-Lysine HCl & 0.35 & 0.40 \\
DL Methionine & 0.30 & 0.40 \\
Total & 100.00 & 100.00 \\
Nutritional Content & & \\
Crude protein (\%) & 22.13 & 20.21 \\
ME (kcal/kg) & $3,143.99$ & $3,201.77$ \\
Crude fat (\%) & 5.30 & 5.41 \\
Crude fiber (\%) & 3.14 & 3.35 \\
Calcium $(\%)$ & 0.92 & 0.90 \\
Available phosphorous $(\%)$ & 0.50 & 0.43 \\
Lysine (\%) & 1.51 & 1.41 \\
Methionine (\%) & 1.41 & 1.35 \\
\hline
\end{tabular}

*Nutritional requirements needs standards for 3-6 week old broiler chickens (NRC, 1994): protein 20\%; Lys $1.0 \%$; Met $0.38 \%$; energy 3,200 kcal $/ \mathrm{kg}$, $\mathrm{Ca} 0.9 \%$; $\mathrm{P}$ av $0.35 \%$.

** Masamix composition per kilogram: vit A 810000

IU, D3 212000 ICU, E 1.8g, K3 0.18g, B1 0.112g, B2 $0.288 \mathrm{~g}, \mathrm{~B} 60.3 \mathrm{~g}, \mathrm{~B} 120.0036 \mathrm{~g}$, Co $0.028 \mathrm{~g}, \mathrm{Cu} 0.5 \mathrm{~g}$, Fe 6.0g; Mn 6g; Iod 0.1g; Zn 5g, Se 0.025g, DL-Met $212.5 \mathrm{~g}$, L-Lys $31 \mathrm{~g}$, Folic Acid 0.11g, As. panthotenat 0.54g. Niacin (vit B3) 2.16g, CholinCl 60\% 75g.

\section{RESULTS AND DISCUSSIONS}

\section{Carcass Production}

The broiler carcass production included slaughter weight, carcass weight, and carcass percentage, are presented in Table 2.

\section{Slaughter Weight}

The slaughter weight of broilers given liquid turmeric generally had the same as those of broilers in a positive control (T1) group that was given the antibiotic zinc bacitracin, except for broilers given $10 \%$ of liquid turmeric extract (T7), which produced a lower significant slaughter weight $(\mathrm{P}<0.05)$. The slaughter weight of broilers given liquid turmeric extract and positive control (T1) were relatively higher compared to those of broilers in the negative control treatment (T2), which was only given plain drinking water. The results revealed that broilers given liquid turmeric extract with a dosage of $8 \%$ (T6) produced the highest slaughter weight and those given turmeric extract dosage of $10 \%$ (T7) produced the lowest slaughter weight.

Fitoni et al. (2013) reported that turmeric with a curcumin active compound could inhibit the growth of coliform bacteria with a total of 108 cfu colonies compared with treatment without turmeric that contained more than $300 \mathrm{cfu}$ of coliform bacteria. The curcumin antibacterial mechanism was that these particles entered the bacteria cell walls by completely damaging the cell walls, so that it resulted in the cell death (Bhawana et al., 2011). There was an inhibition of pathogen bacteria, resulting in a reduction of nutrients in the intestine that were eaten by the pathogen bacteria, so that the absorbed nutrition by intestinal villi increased.

The research also showed that giving a 10\% dosage of liquid turmeric extract (T7) could reduce the broiler slaughter weight, after the previous T6 (dosage of $8 \%$ ) showed the highest slaughter weight. The same research results were reported by Pratikno (2010) that giving a turmeric extract dosage of $400 \mathrm{mg} / \mathrm{kg}$ body weight had the highest body weight $(2,320.833 \mathrm{~g})$. However, giving a turmeric extract dosage of $600 \mathrm{mg} / \mathrm{kg}$ body weight actually reduced the body weight $(2,251.667 \mathrm{~g})$.

Curcumin was found to experience a character shift from an antioxidant to become a prooxidant when it was given in a high dosage (Saefudin et al., 2014). Research by Syamsudin $e t$ al. (2006) revealed that giving a curcumin dosage of $3,600 \mu \mathrm{M}$ in rat liver mitochondria isolate reduced the glutathione reductase (GR) enzyme activity compared with the curcumin dosage of 60 $\mu \mathrm{M}$ which was lower. The lower GR activity could be caused by an accumulation of free radical metabolites. The free radical compound could originate from curcumin which had a trait shift to become a prooxidant in a high dosage. The body need more energy to detoxify free radical compounds. The amount of energy needed 
Table 2. Carcass Production of Broilers Given Liquid Turmeric Extract in Drinking Water

\begin{tabular}{cccc}
\hline Treatments & Slaughter Weight $(\mathrm{g})$ & Carcass Weight $(\mathrm{g})$ & Carcass Percentage \\
\hline T1 & $2,917.7 \pm 87.36^{\mathrm{b}}$ & $2,101.2 \pm 77.81$ & $72.01 \pm 1.38$ \\
T2 & $2,774.7 \pm 126.82^{\mathrm{ab}}$ & $1,974.2 \pm 127.27$ & $71.13 \pm 2.75$ \\
T3 & $2,832.7 \pm 193.90^{\mathrm{b}}$ & $2,105.3 \pm 206.88$ & $74.45 \pm 7.27$ \\
T4 & $2,761.2 \pm 210.59^{\mathrm{b}}$ & $1,987.3 \pm 148.04$ & $72.24 \pm 6.57$ \\
T5 & $2,816.3 \pm 31.00^{\mathrm{b}}$ & $2,031.3 \pm 78.30$ & $72.14 \pm 2.92$ \\
T6 & $2,931.8 \pm 62.11^{\mathrm{b}}$ & $2,003.0 \pm 69.00$ & $68.32 \pm 1.79$ \\
T7 & $2,644.2 \pm 178.51^{\mathrm{a}}$ & $1,869.2 \pm 161.77$ & $71.02 \pm 8.56$ \\
\hline
\end{tabular}

Mean at the same column with different superscript indicate significantly different $(\mathrm{P}<0.05)$; T1: Positive Control T2: Negative Control; T3: Turmeric Extract 2\%; T4: Turmeric Extract 4\%; T5: Turmeric Extract 6\%; T6: Turmeric Extract 8\%; T7: Turmeric Extract 10\%

would increase the total metabolizable energy in broiler chicken blood (Sundari, 2014), so that it would reduce the feed consumption, resulting in a decrease of body weight. The decrease of body weight was proven from research conducted by Kusmayadi (2015), who found that the feed intake of broiler given $10 \%$ dosage of liquid turmeric extract was only $3,285 \mathrm{~g}$ compared to those of broiler given $8 \%$ dosage of liquid turmeric extract $(3,723 \mathrm{~g})$. The lower feed intake caused the insufficient broiler nutrient needs in terms of quantity, so that the growth disrupted and the body weight decrease.

\section{Carcass Weight and Dressing Percentage}

The carcass weight and dressing percentage did not show a significant difference $(\mathrm{P}<0.05)$ among the treatments. Nevertheless, substantially, There was a positive correlation between the carcass weight and the slaughter weight. This is in accordance with a statement by Mahfudz et al. (2009) that the final body weight was equivalent with the carcass weight. Carcass reflected body part of the broiler production (Resnawati, 2004) and the carcass percentage reflected the size of the broiler carcass.

\section{Meat Chemical Quality}

The results of the broiler meat chemical quality, which are included protein content, fat content, and meat water content are presented in Table 3.

\section{Meat Protein Content}

The broiler meat protein content, which was supplemented with $2 \%$ to $10 \%$ doses of turmeric extract in drinking water generally had the same protein content compared to the positive control and negative control with a range of 21.49 to $23.94 \%$. Six-week old male broiler meat protein content was ranged from 20.21 to $22.08 \%$ (Soeparno, 2011), so that this results were relatively normal.

Sundari (2014) explained that by giving turmeric extract, it would increase the nutrient absorption capacity, including protein, in the small intestine. Turmeric extract as a phytobiotic was also found to accelerate nutrient metabolism in cells (Pratikno, 2010). A smooth metabolism could be due to the curcumin activity in turmeric extract, which functions as an imunomodulator or antibody system (Dono, 2013). Jamilah et al. (2013) stated that good broiler immunity caused protein to be used to repair cell tissues, so that a high amount of protein was deposited inside meat. On another side, the body's low immunity causes protein to be mostly used to repair cell tissues as well as form antibodies. Increasing the protein deposit in meat will be used for growth and not to increase the percentage of meat protein.

\section{Meat Fat Content}

The broiler meat fat content, which was supplemented with turmeric extract in drinking water with a dosage of $2 \%$ to $10 \%$, generally had the same fat content $(\mathrm{P}>0.05)$ as positive control or negative control did. Sundari (2014) reported that giving turmeric extract could increase the fat nutrient absorption in the small intestine. This reflecting that fat which was absorbed in the body 
Table 3. Meat Chemical Content of Broiler Chickens Given Liquid Turmeric Extract in Drinking Water

\begin{tabular}{cccc}
\hline Treatments & Protein content $(\%)$ & Fat content $(\%)$ & Water content $(\%)^{*}$ \\
\hline T1 & $23.44 \pm 0.07$ & $0.98 \pm 0.20$ & $73.08 \pm 0.57^{\mathrm{b}}$ \\
T2 & $21.49 \pm 3.00$ & $1.74 \pm 0.23$ & $73.41 \pm 0.33^{\mathrm{b}}$ \\
T3 & $22.47 \pm 0.34$ & $1.80 \pm 0.52$ & $72.91 \pm 0.42^{\mathrm{b}}$ \\
T4 & $22.73 \pm 0.49$ & $2.21 \pm 0.68$ & $73.14 \pm 0.84^{\mathrm{b}}$ \\
T5 & $23.93 \pm 0.41$ & $1.41 \pm 0.23$ & $73.07 \pm 0.77^{\mathrm{b}}$ \\
T6 & $23.74 \pm 0.33$ & $2.13 \pm 0.51$ & $71.80 \pm 0.80^{\mathrm{a}}$ \\
T7 & $23.94 \pm 0.43$ & $1.78 \pm 1.20$ & $71.96 \pm 0.43^{\mathrm{a}}$ \\
\hline
\end{tabular}

Mean at the same column with different superscript indicate significantly different $(\mathrm{P}<0.05)$; $\mathrm{T} 1$ : Positive Control T2: Negative Control; T3: Turmeric Extract 2\%; T4: Turmeric Extract 4\%; T5: Turmeric Extract 6\%; T6: Turmeric Extract 8\%; T7: Turmeric Extract 10\%

would increase and deposited in the body, including meat in the form of intramuscular fat. Linder (1992) added that body fat also came from the conversion of excess glucose. On another side, Estancia et al. (2011) explain that curcumin had increased lipid catabolism to decrease lipid in the body. In this research, the increase of lipid metabolism did not occur due to the ration which was fulfilled with energy from glucose. This sufficiency caused the fat unable to breakdown to become physical or heat energy, so that there was no reduction in broiler meat fat content.

\section{Meat Water Content}

The meat water content of broiler which were given liquid turmeric extract revealed significant differences among the treatments $(\mathrm{P}<0.05)$. The liquid turmeric extract treatments of $2 \%$ until $6 \%$ did not show any significant differences compared to the positive and negative controls, but they showed a significant difference $(\mathrm{P}<0.05)$ in $8 \%$ and $10 \%$ doses. The higher dry matter content of meat had automatically increased other nutrients value of the meat. The water content was found to have a positive correlation with the protein content. According to Soeparno (2011), this was in regards to the muscle protein that had a hydrophilic trait, meaning it interacted with water to form hydrogen bonds (binding meat water molecules).

In vitro research which was conducted by Sundari (2014), revealed that the addition of turmeric extract could improve the digestion of dry matter, protein, and fat, because of the increase in number and height of intestinal villi, so that the area of the intestinal villi surface to absorb nutrients increased. A greater number of absorbed nutrients and better metabolism process because of the curcumin caused higher deposited nutrients in the meat, so that the dry matter of meat increased and the meat water content decreased.

\section{CONCLUSION}

Providing liquid turmeric extract in the dossage $2 \%$ to $8 \%$ had the similar results of slaughter weight. Providing liquid turmeric extract (8 to $10 \%$ ) can also reduce the water content in broiler meat. However, using liquid turmeric extract with a $10 \%$ of dosage has a negative effect in the reduction of the slaughter weight.

\section{ACKNOWLEDGMENTS}

An expression of gratitude is conveyed to the General Directorate of Higher Education, the UGM Animal Science Faculty academic community, and especially to the UGM Animal Science Students' Study Forum (FOSMAPET) for their assistance in conducting the field research.

\section{REFERENCES}

AOAC. 2005. Official Method of the Association of Official Analytical Chemist. 12 $2^{\text {th }}$ Edition. Published by the Association of Official Analytical Chemist. Benjamin Franklin Station. Washington DC. 
Astuti, M. 1980. Rancangan Percobaan dan Analisis Statistik Bagian 1. Bagian Pemuliaan Ternak Fakultas Peternakan UGM. Yogyakarta.

Ajit, S.Y., G. Kolluri., M. Gopi., K. Karthik., Y. Malik and K. Dhama. Exploring alternative to antibiotics as health promoting agents in poultry - a review. J. Exp. Biol. Agric. Sci. 4:368-383.

Ashayerizadeh, A., N. Dabiri, O. Ashayerizadeh, K. H. Mirzadeh, H. Roshanfekr, and M. Mamooee. 2009. Effect of dietary antibiotic, probiotic, and prebiotic as growth promotores on growth performance, carcass characteristics and hematological indices of broiler chickens. Pakistan J. Biol. Sci. 12:5257.

Badan Pusat Statistik. 2015. Data Peternakan Indonesia. Badan Pusat Statistik.

Barton, M.D. 2000. Antibiotic use in animal feed and its impact on human health. Nutrition Research Reviews 13:279-299.

Bhawana, R.K. Basniwal, H.S. Buttar, V.K. Jain and N. Jain. 2011. Curcumin nanoparticles: preparation, characterization, and antimicrobial study. J. Agric. Food Chem. 59:2056-2061. (Abstr.).

Bintang I.A.K., A.P. Sinurat and T. Purwadaria. 2008. Penambahan antibiotika dan ampas mengkudu sebagai senyawa bioaktif terhadap performans ayam broiler. JITV 13:7-12.

Daud, M., W.G. Piliang, and I.P. Kompiang. 2007. Persentase dan kualitas karkas ayam pedaging yang diberi probiotik dan prebiotik dalam ransum. JITV. 12:167-174.

Dono, N.D. 2012. Nutritional Strategies to Improve Enteric Health and Growth Performance of Poultry in The Post Antibiotic Era. PhD Thesis. The College of Medical, Veterinary and Life Sciences, University of Glasgow, Glasgow.

Dono, N.D. 2013. Turmeric (Curcuma longa Linn.) supplementation as an alternative to antibiotics in poultry diets. Wartazoa. 23:4149.

Fitoni, C.N., M.T. Asri and M.T. Hidayat. 2013. Pengaruh pemanasan filtrat rimpang kunyit (Curcuma longa) terhadap pertumbuhan koloni bakteri coliform secara in vitro. Lentera Bio. 2:217-221.

Gunal, M. G. Yali, O. Kaya, N. Karahan and O. Sulak. 2006. The effect of antibiotic growth promotor, probiotic, or organic acid supplementation on performance, intestinal microflora and tissue of broiler. International J. Poul. Sci. 5:149-155.

Hartadi, H., Kustantinah, Zuprizal, E. Indarto and N.D. Dono. 2008. Nutrisi dan Pakan Ternak (PTN 3302). Fakultas Peternakan UGM. Yogyakarta. pp. 62-63.

Hintono, A., M. Astuti, H. Wuryastuti, and E. S. Rahayu. 2007. Residu oksitetrasiklin dan aktivitas antibakterinya dalam telur dari ayam yang diberi oksitetrasiklin dengan dosis terapeutik lewat air minum. J. Indonesian Trop. Anim. Agric. 32:64-70.

Jamilah, N. Suthama and L.D. Mahfudz. 2013. Performa produksi dan ketahanan tubuh broiler yang diberi pakan step down dengan penambahan asam sitrat sebagai acidifier. JITV. 18:251-257.

Kusmayadi, A. 2015. Pengaruh Nanokapsul Ekstrak Kunyit Sediaan Cair dalam Air Minum Terhadap Performan dan Perlemakan Ayam Broiler. Thesis. Fakultas Peternakan, Universitas Gadjah Mada, Yogyakarta.

Linder, M.C. 1992. Biokimia Nutrisi dan Metabolisme. (A. Parakkasi, eds). Penerbit Universitas Indonesia. Jakarta.

Mahfudz, L.D., F.L. Maulana, U. Atmomarsono and T.A. Sarjana. 2009. Karkas dan lemak abdominal ayam broiler yang diberi ampas bir dalam ransum. Proceedings of Seminar Nasional Kebangkitan Peternakan, Semarang, Indonesia, May 20, 2009. P. 596605.

NRC. 1994. Nutrient Requirements of Poultry. $9^{\text {th }}$ ed. National Academy of Science. National Research Council, Washington DC.

Prasanth, K.G., E. Kalpana, B. Dineshkumar, E. Monogaran, G. Geetha and R. Venkatanarayanan. 2012. Tetrahydrocurcumin: Beneficial effects of HMG-CoA reductase enzyme and lipoprotein lipase enzymes in high fat diet-induced hypercholesteremia rabbits. Pharmacognosy Communications. 2:50-60.

Pratikno, H. 2010. Pengaruh ekstrak kunyit (Curcuma domestica vahl) terhadap bobot badan ayam broiler (Gallus sp). Buletin Anatomi dan Fisiologi. 18:39-46.

Rahmawati, N., E. Sudjarwo and E. Widodo. 2015. Uji aktivitas antibakteri ekstrak herbal terhadap bakteri Escherichia coli. Jurnal Ilmu-Ilmu Peternakan 24:24-31.

Resnawati, H. 2004. Bobot potongan karkas dan lemak abdomen ayam ras pedaging yang diberi ransum mengandung tepung cacing 
tanah (Lumbricus rubellus). Seminar Nasional Teknologi Peternakan dan Veteriner 2004.

Saefudin, F. Syarif and Chairul. 2014. Potensi antioksidan dan aktivitas antiproliferasi ekstrak kunyit putih (Curcuma Zedoaria Rosc.) pada Sel Hela. Widyariset. 17:381390.

Soeparno. 2011. Ilmu Nutrisi dan Gizi Daging. Cetakan ke-1. Gadjah Mada University Press. Yogyakarta.

Sinurat, A.P., T. Purwadaria, I.A.K. Bintang, P.P Ketaren, N. Bermawie, M. Raharjo, and M. Rizal. 2009. Pemanfaatan kunyit dan temulawak sebagai imbuhan pakan ayam broiler. JITV. 14:90-96.
Sundari. 2014. Nanoenkapsulasi Ekstrak Kunyit dengan Kitosan dan Sodium-Tripolifosfat sebagai Aditif Pakan dalam Upaya Perbaikan Kecernaan, Kinerja, dan Kualitas Daging Ayam Broiler. Disertasi. Fakultas Peternakan, Universitas Gadjah Mada, Yogyakarta.

Syamsudin, F.D. Suyatna, S. Ganiswarna and M. Sadikin. 2006. Efek kurkumin terhadap aktivitas enzim glutation reduktase mitokondria hati tikus yang diinduksi dengan butilhidroperoksida tersier (t-BHP). JKM 6:33-39.

Widiastuti, R. 2008. Residu enrofloksasin dan siprofloksasin pada ayam pedaging pasca pencekokan enrofloksasin. JITV. 13:150-154. 